is taken of the galvanometer, first to left, then to right, and the shunt-resistance is then adjusted until the scale reading is $53 \frac{1}{2}$ millimetres on either side of zero, making a total of 107 millimetres. We then know that a deflection of I millimetre right or left will be produccd by an electromotive force of $\mathrm{I} / 200$ of a volt. The cell whose electromotive force is to be tested is then substituted at $\mathrm{B}$ in place of the standard cell, and readings taken right and left ; these are added, and divided by 100 , giving the E.M.F. of the cell directly in volts.

To measure currents the same calibration is made with a standard cell. In the circuit of the current to be measured is interposed a wire of some small but accuratelyknown resistance-for example, a standard $\mathrm{I}$ ohm, or, for stronger currents, a standard wire of $\mathrm{O}^{\circ} \mathrm{I}$ ohm. The two extremities of this coil are then connected to the key (Fig. 3), the I0,000-ohm coil being interposed as before. If the current to be measured is I ampere, it will, in passing through the standard $\mathrm{I}$ ohm, produc

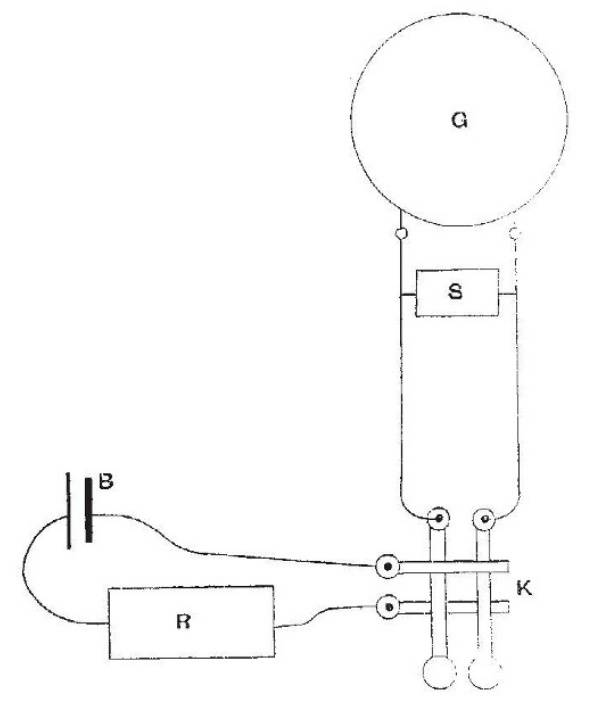

Fig. 3.

between its ends a difference of potential of $\mathrm{I}$ volt, and this difference of potential will, when readings are taken right and left, give a total defiection of 100 millimetres to correspond to I ampere of current. It is not difficult to modify the arrangements so that the galvanometer may measure, on the one hand, millionths of an ampere, and thousands of amperes on the other. We have found the instrument specially valuable for indicating rapid fluctuations of current in experiments on the induction of currents in armature coils when moved in a magnetic field. Its complete aperiodicity and the very small inertia, both mechanical and electrical, of its coil, render it most valuable for such work. The only defect-and that not a serious one-observed in three months of use, is a slight sub-permanent torsion on the suspending wires after taking a large deflection; but the method of taking double readings, first to right, then to left, climinates any error that might arise from this cause.

\section{THE BASALT-FIELDS OF NEW MEXICO}

CELOGISTS interested in the history of the younger G lava-floods, by which such vast areas both in the Old World and in the New have been deluged, will be glad to know that Capt. Dutton, of the United States Ceological Survey, after a careful study of the modern volcanic phenomena of the Sandwich Islands, has under$\mathrm{t}^{\text {aken }}$ the investigation of the basalt-territory lying in
New Mexico, to the east and south of the area already so fully described by him in his Monographs on the Utah plateaux and the Cañon country. It was originally intended that he should have charge of the Survey of the Cascade Range. This arrangement was changed at the beginning of this last season. The Cascade ground was intrusted to his able assistant, Mr. Diller, while Capt. Dutton himself struck southward for a region in New Mexico, which he had long wished to study, from the light which he believed it would throw upon some of the later phases of volcanism in the Western Territories. I have received a long letter from him, written in his camp at the San Mateo Mountains, from which, with his permission, I send the following extract for publication in NATURE.

ARCH. GeIKIF.

Our wonderful Plateau Country we have known only in part, and the portion we have studied most is situated upon the western and northern side of the Colorado. Numerous geologists have hurried over the southern and south-eastern portion ; but so rapidly have they been obliged to move in order to keep pace with the expeditions of which they were merc appendages that very little systematic knowledge could be gained. During the last two years our topographers have made some excellent maps of this region, and everything is ripe for the geologist.

I have described the western and southern portions of the Plateau Country as being very sharply defined in a geological as well as in a topographic sense. I think it will in great part prove to be equally well-defined in the south-eastern portions. Already it is clear to me that the Rio Grande River constitutes a portion of that boundary in this territory. Everywhere within range of my present field the strata characteristic of the Plateau Country rise gently from the Rio Grande to the westward. Cliffs, mesas, and terraces, carved buttes, and gorgeous colours are as typical of this region as they are of Utah and Northern Arizona. There is, however, more of the Cretaceous system preserved, and rocks of that age predominate, though the Trias and Permian are magnificently exposed. Indeed, the Vermilion Cliffs of Southern Utah have reappeared here in all their grandeur and glory, with but slight changes of detail.

But the features which are engaging my particular attention at this moment are the volcanic vestiges. This region has long been known under the mysterious name of Malpais-mysterious, however, only to those who have not read Humboldt's account of the malpais of Old Mexico. All the mesas, or platforms of sedimentary beds, within three or four miles of my camp, are sheeted over with basalt. The lava caps are not ordinarily more than fifty or a hundred feet thick; though just around me, in the very centre or focus of all, it bccomes much thicker. In the valley-plains, also, are found many sheets of lava. But while the lavas upon the higher platforms and terraces are ancient, those in the valleys are very young. The centre of the activity has been (so far as concerns my present vicinity) the San Mateo Mountains. This name is synonymous with Mount Taylor, for the "Mountains" consist of a single volcanic pilc ( 11,380 feet) carved into numerous spurs by magnificent gorges. It is a small Etna, built originally by outbreaks from its flanks as well as its summit. But the spread of the lavas from this centre is remarkable. To the north-north-east they reach out in unbroken continuity for forty-five miles, and for eighteen to thirty miles in the other directions. The lava beyond the immediate base of the mountaincone is not thick. It forms a superficial sheet only on each mesa, or table, with a thickness varying from 50 to 200 feet.

The lava-capped strata have been cut into isolated mesas by subsequent crosion, and gaps of two or three miles sometimes separate one of these outliers from its parent mass. 
This lava did not by any means come altogether from Mount Taylor itself, but from many vents scattered around its flanks, or situated miles away from it. These outlying vents are sufficiently preserved in many cases to admit of their complete identification, and they are very numerous. But one of the most charming and striking features consists in the numerous "necks" or "chimneys" which are left standing in the valley-plains beyond the farthest verge of the lava-capped mesas. Some of these are splendid objects. Newberry has depicted similar forms in the valley of the San Juan-a hundred miles or more to the north-west of here---in his admirable account of the observations made in his journey with Capt. Macomb's expedition. But these are even larger and finer, one being nearly two thousand feet high. What perfect testimony this is to the enormous erosion of the country! A child can read and comprehend it.

In the wide valley-plains which lie between the mesas are fresher fields of lava. Some look as if they could hardly be a century old; but my experience in the Hawaiian Islands has taught me that, in a dry country, a basalt-stream can preserve its freshness for many centuries. Still, it is clear enou, $h$ that these eruptions occurred after hundreds, even thousands, of square miles of strata, overflowed by the older basalts, had been eroded away.

A striking fact in connection with these young basalts is the entire absence of all distinguishable traces of the vents from which they came. A few miles from here, in a broad valley, lies a basalt-field blac's as Erebus, and the whole circuit of it as accessible as a sheet of paper on a table, or a rug on the floor. There is no cone, no trace of fragmental ejecta, not a single feature in it to indicate the locus of eruption, except, however, the fact that the whole field, and the valley in which it lies, has a gentle declivity to the south-east, say forty feet per mile or so: and as the sheet follows the modern slope of the valley, it may be inferred that the vent is situated near the northwest end. There are many other fields of fresh lava, of which the above is sufficiently descriptive. One stream is nearly sixty miles long! Some of them, however, indicate unmistakably their sources in small depressed cones of very flat profiles. Great deluges of basalt have issued from them, flowing away for many miles, and spreading out five or six miles wide.

No fragmental ejecta (scoria, lapilli, \&c.) have been found in connection with these young eruptions. But on Mount Taylor are numerous parasitic cinder-cones, of small or moderate dimensions, formed during the period of the eruption of the older basalts. The quantity of this fragmental material, however, is relatively very small.

The appearance of the young basalts is much like the rougher lava of Mauna Loa, called "aa" in the Hawaiian Islands. This is the typical malpais of this region. All the lava thus far seen is apparently basalt, though some of the older may prove to be andesitic when critically examined. There is little variety in it. It now appears that, all along the western, southern, and southeastern rim of the Plateau Country is a marginal belt characterised by basaltic eruptions. I have identified two agcs of eruption, both here and in South-West Utah. In the latter region I have associated these two periods of eruption with two periods of general upheaval of the plateaux. Whether the same will prove to be so here remains to be seen.

But it is getting dark, and I must close. We go to bed and get up with the chickens in this country.

\section{E. DUT'TON}

\section{NOTES}

A MeETrNG of members of the University and others, to promote the objects of the Marine Biological Association, will be held at Cambridge on Saturday next, the 2gth inst., in the
Lecture-Room of Comparative Anatomy, the use of which $f(r$ this purpose was granted to Prof. Newton by grace of the Senate on Thursday last. The Vice-Chancellor of the Un:versity (Dr. Ferrers, F.R.S., Master of Gonville and Caius College) has kindly undertaken to preside; and Prof. Moseley (the Chairman of the Council of the Association), Prof. Lankester (its Secretary), and Prof. tell, of the British Museum and King's College, London, are expected to attend and set forth the aims and needs of their deserving body. The chair will Le taken at three o'clock in the afternoon, and the proceedings (the details of which are being arranged by Mr. J. W. Ciark, Superintendent of the Museum of Zoology and Comparative Anatomy, and Mr. Sedgwick, University Lecturer in Animal Morphology) are likely to be full of interest. The same evening the anniversary dinner of the Cambridge Philosophical Society will be given in the hall of Peterhouse, on the special invitation of the Master and Fellows of that ancient college, the newly-elected President of the Society, Prof. Foster, Sec. K.S., in the chair.

Tile German Government has granted another sum of $7500 \%$. for the scientific investigation of Central Africa, and 1900l. for the working out of the materials collected by German Polar expuditions.

TIIERE seems to be no end to the works of the highest value issued from the American Nautical Almanac Office. This week we have received a paper on "The Motion of Hyperion-a New Case in Celestial Mechanics," by Prof. Simon Newcomb; and another on "Lunar Inequalities due to the Ellipticity of the Earth," by Mr. G. W. Hill.

AT the first meeting of the new session of the Society of Arts held on November I9, Sir Frederick Abel made some feeling and pregnant remarks on the loss that not only the Society of Arts, but the whole scientific world, had sustained by the sudden and unexpected death of Sir William Siemens. In the course of his address Sir Frederick Abel said :- " "It will be in the recollection of many whom I am addressing that, while Sir William Siemens was an ardent and successful labourer in the advancement of electric lighting, he also maintained the view that gas would continue to hold its own as the poor man's friend. The name of Siemens is associated with the origination of a great advance in the application of gas to the brilliant illumination of open spaces; but it must also be conceded that many streets and public places in London and the provinces bear evidence that even such simple modifications in the arrangement of old forms of gas-burners as have been introduced by Sugg and others have restored to gas some of its original prestige, and that, especially in towns where fogs are periodically prevalent, gas is now by no means wholly eclipsed by electricity as an open-air illuminant."

LAST week we announced the death of Dr. Wright of Cheltenham; to-day we have to make known that another of the lights of English geology has passed away. Mr. R. A. Godwin. Austen died at his residence, Shalford House, Guildford, on the morning of the $25^{\text {th }}$ inst., after a long, but happily not a painful illness. He has for so many years lived retired in his country home that the younger generation of geologists has hardly known him personally. But his papers are classical in the literature of English geology, and long ago marked him out as one of the most philosophical of all the geological writers of this country.

Mk. James Buckman, formerly one of the Professors at the Royal Agricultural College, Cirencester, and author of a number of geological papers, died at Bradford Abbas, Dorset, on the $23 \mathrm{rd}$ inst.

THE death is announced of Herr August Wilhelm Thienemann, the President of the German Society for the Protection of Birds, well-known in ornithological circles by his researches 